\title{
Significance of Rasa and Abhinaya Techniques in Bharata's Natyasastra
}

\author{
Dr. C. S. Srinivas \\ Assistant Professor, Mahatma Gandhi Institute of Technology Hyderabad, India - 500075.
}

The Natyasastra of Bharata consists of thirty-six chapters in all. The first three chapters respectively deal with the origin of drama, the erection of theatre and the worship of the stage. Chapter 4 deals with the varieties of dance. Chapter 5 is devoted to the conduct of purvaranga or 'preliminary rites.' Chapters 6 and 7 relate to rasas ("sentiments") and bhavas ("emotions"). Chapters 8 to 14 (inclusive of 14)) are set apart for a discussion on angikabhinaya. The eight chapters from 15 to 22 deal with vacikabhinaya and related topics. In chapter 23 aharyabhinaya is treated. The next six chapters-from 28 to 33 (inclusive of 33) contain details about instruments and music. The last three chapters of the treatise, 34 to 36 (inclusive of 36) provide details regarding the different characters, varieties of costumes and popularization of the art of histrionics. This, in short, is the summary of the contents of the Natyasastra.

The concept of rasa is unique to Indian poetics and dramatics and is essentially a creation of the Indian genius-Bharata. With his succinct and organized presentation Bharata carved a niche rasa-sutra in the annals of poetics and dramaturgy. He presented rasa formula in context to natya in his Natyasastra. Later on the rasasutra became the touchstone for all the poetics. The aim of a dramatic performance is to evoke sentiment or rasa in the mind of the sahrdaya or the 'learned audience'. In chapter 6 of Natyasastra, Bharata elaborately discusses on the significance of rasa and its essential role in the production of a play.

"Nothing proceeds on the stage without reference to rasa' is Bharata's most important pronouncement" says Raghavan in his research paper entitled "Sanskrit Drama in Performance" (21). The Sanskrit word rasa fundamentally means 'taste' or 'flavour' or 'savour' or 'relish'. In a metaphorical sense it refers to "the emotional experience of beauty in poetry and drama" (Kane 356). The ultimate goal, purpose of writing, presenting and viewing a play is to experience rasa realization.

According to Bharata, rasa or 'sentiment' is the mental condition of delectation produced in the spectator of a play or in the hearer or the reader of poem, as the inevitable reaction of the bhavas or emotions manifested by the characters. He gives a detailed account of the eight different rasas, or 'sentiments', namely, sringara or 'the erotic', vira or 'the heroic', karuna or 'the pathetic', hasya or 'the comic', raudra or 'the furious', bhayanaka or 'the terrible', bibhatsa or 'the odious' and adbhuta or 'the marvellous.'

It has been found that no one word or phrase is adequate to convey the total meaning of rasa. Rasa is actually the impression created on the mind of the sympathetic audience by the expression of bhavas or 'emotions' and is an experience the individual is subjected to on account of this expression. Bhava is the emotion that creates a sense of enjoyment or experience which in itself is an entity and that enjoyment or experience is rasa.

Next, Bharata gives an account of bhavas ("emotions"). He explains that there are three types of bhavas: sthayi-bhavas ("static emotions"), sancari-bhavas or also called vyabhicari-bhavas ("transitory emotions") and the third is sattvika-bhavas ("responsive emotions").The sthayi-bhavas are eight in number and they correspond to the eight sentiments and they are: rati ("love"), hasa ("mirth"), soka ("grief"), krodha ("anger"), utsaha ("enthusiasm"), bhaya ("fear"), jugupsa ("aversion"), and vismaya ("wonder").

The vyabhicari-bhavas or the sancari-bhavas are thirty-three in number. They are: nirveda ("dejection"), glani ("depression"), sanka ("suspicion"), asuya ("jealousy"), mada ("intoxiation"), srama ("weariness"), alasya ("laziness"), dainya ("helplessness"), cinta ("anxiety"), moha ("passion"), smriti ("recollection"), dhrti ("boldness"), vrida ("shame"), capalata ("fickleness"), harsya ("joy"), avega ("agitation"), jadata ("stupor"), garva ("arrogance"), visada ("despair"), autsukya ("inquisitiveness"), nidra ("sleep"), apasmara ("epilepsy"), supta (“dream"), vibodha ("awakening”), amarsa ("intolerance"), avahittham ("concealment"), ugrata ("ferocity"), mati ("knowledge"), vyadhi ("sickness"), unmad ("insanity"), maranam ("death"), trasa ("fright") and vitarka ("doubt"). The sattvika-bhavas are also eight. They are stambha ("stunned"), sveda ("sweating"), romanca ("thrill"), svarabheda ("break in voice"), vepathu ("trembling"), vaivarnya ("pallor"), asru ("tears") and pralaya ("swoon") (Natyasastra ch.6 par. 14-22).

Normally incidents that cause pain in real life create depression in human beings. But when the same incidents are described in a work of art or presented on the stage, an inexplicable pleasure is derived by human beings and that is rasa. The actor interprets not only what is literal in the text, but also contributes his own by 
way of sub-text which is more implied than explicit and with his creative talent fills up the blanks that have been left over by the author. The imagery created on the stage with the expression of bhava produces rasa in the minds of the audience and makes the representation thoroughly enjoyable. Thus it is an experience shared equally by the author, the actor and the audience.

Asha Choubey in her article "Sophocles and Indian Poetics: A study of Oedipus in the Light of Rasa Theory" quotes Bharata's rasa-sutra, "Vibhavanubhava-vyabhicari-sanyogad rasanispatih" and gives its English translation like this: "The realisation of rasa results from the union of three elements-vibhava, anubhava and vyabhicari" (24). The root-cause or the excitant that creates the emotion is called vibhava or the 'determinant.' So, vibhava is the cause and bhava is the effect. The voluntary expression following the emotion caused by the determinant is called anubhava or the 'consequent.' Although the words vibhava and anubhava incorporate the word bhava it may be noted that they are not bhavas. Vibhava, anubhava and bhava are thus intimately connected with one another. The bhavas when expressed must be natural with their roots in the actual happenings in the world.

Bharata in his Natyasastra has classified forty-nine such emotions into three main categories. They are sthayi or 'static', sancari or vyabhicari or 'transitory' and sattvika or 'responsive' emotions. The emotions that are retained in the minds of the audience till rasa is created are called sthayi-bhavas. The passing emotions that contribute to the creation of rasa are classified as sancari-bhavas. The physical involuntary expressions that manifest themselves as a result of the intensity of emotion in the mental plane are called sattvika-bhavas. Bharata states that a configuration of these forty-nine emotions promotes the creation of rasa in the minds of the sympathetic audience.

The Natyasastra explains that a 'sentiment' or rasa is produced by the union of determinantsvibhava, the consequent-anubhava and the transitory emotions—vyabhicari. The determinants again fall into two classes - the alambana which are the fundamental determinants as the hero and the heroine, as without them there can be no creation of rasa in the audience. The second one is the contributory determinants the uddipana such as place, time and circumstances, the purpose of which is to foster the sentiment which has arisen. Examples of uddipana for sringara rasa would be things such as soft cool breeze, the moon, smell of flower etc. that would foster the sentiment of love. While these constitute the vibhava, the anubhavas are the external manifestations of feeling by which actors communicate their mind and heart to the audience. Actors and actresses use eye-glances, smiles, movements of the limb etc. to indicate their feelings through actions and these constitute the anubhavas. The Natyasastra, however, recognizes that these factors are insufficient for the production of rasa. The emphasis is on the fact that the essential element for producing rasa is the sthayibhava - the dominant emotion, which persists throughout the drama amid the variations of the transitory feelings which come and go.

If rasa is the purpose of Sanskrit drama then the tool, which is utilized to bring about rasa, is abhinaya. The word abhinaya means that which brings the thing to the spectator, or the different ways in which the actor brings the play with its meaning and feelings to the spectator. The word is derived from the root ' $n i$ ' which means 'take' or 'carry', with the preposition 'abhi' meaning 'towards.' This is what the traditional verse saysthe root ' $n i$ ' with the preposition 'abhi' which means 'towards', is given the word abhinaya, because it carries (ni-) the performance towards the audience (Natyasastra ch.8 par. 5-10). Abhinaya, therefore, occupies the foremost place in Sanskrit drama. But for abhinaya the very purpose of Sanskrit drama that is the realization of rasa will not be achieved. Thus, the concept of abhinaya expounded in the Natyasastra is a comprehensive one, covering the whole range of acting possibilities.

Bharata says in his Natyasastra, that there are four kinds of abhinaya. The four types are angika ("physical"), vacika ("verbal"), sattvika ("emotional") and aharya ("make-up and costumes" or "material"). It can be said that Sanskrit drama was essentially written only for performance and dramatists were well aware of the merits that would accrue to their works if all these four elements of abhinaya were properly interposed and presented along with the accessories of dance, music and song.

Angikabhinaya: Bharata devotes six chapters beginning from chapter eight to chapter thirteen to angikabhinaya alone. Angikabhinaya means to convey the meaning through bodily movements. Bharata's description of angika is the detailed study of all the possible gestures, postures and movements of each and every part of the body. According to Bharata, angikabhinaya can be executed in three chief ways, namely, sarira which means acting by means of limbs, mukhaja, acting by means of face and cestakrta that is acting by means of the movements of whole body (qtd. in Bose 127).

In sarirabhinaya, the different kinds of the movements of the chest, the sides, the waist, the abdomen, the thighs, the shanks and the feet are defined and Bharata also indicates the occasions for their use. These actions are to be employed during the representations of the various roles as necessitated by the situation. The movements of the chest, the sides, the waist, the thighs, the shanks and the feet are of five types each. The movements of the abdomen are of three types. 
Mukhaja represents, head, face and neck of the human body. There are thirteen types of the movements of the head each depending on the direction in which the head is moved, the degree of its movement as well as how quickly the movement is made. The eyes play the most important role with regard to the expressions of feelings and emotions. In a dramatic performance, all the bhavas and the rasas are expressed through the eyes. The bhava is first indicated by eyes and then represented by limbs. Marasinghe suggested that Bharata mentions thirty-six different types of dristis or 'eye-movements' in his Natyasastra (235). Eight of them known as rasadristis correspond to the eight sentiments, and another group of eight called sthayi-dristis represent the eight sthayi-bhavas and the remaining twenty eye movements known as sancari-dristis are related to the depiction of the vyabhicari-bhavas. Another detail is regarding the movements of the pupils of the eye, which are nine. The modes of glances are eight. Yet another detail is related to the movements of the eye lashes, which are nine. The movements of the eyebrows are of seven types. The movements of the nose, cheeks and of the lips are of six kinds. The movement of the chin is of seven types. The mukhakarma which denotes the actions of the face are of six varieties. The actions of the neck are of nine types.

Conveying the meaning through hastas or 'hand-gestures' known as hastabhinaya is an important aspect of cestakrta. The tradition of using hastas as expounded by Bharata and followed by the later Sanskrit drama theorists is still very much alive in the Indian classical dance traditions such as Bharatanatyam, Kathakali and Odissi etc. Hastas are of two types, namely, asamyukta (executed with one hand) and samyukta (a formation with both hands together). Bharata has also defined the hasta-pracara ("hand positions"), hastarecaka ("simultaneous hand and arm movements") and hasta-karana ("the turning movement of hand'). Similarly, there are cari movements that suggest the different types of gait, movements involving the exercise of the feet. They are thirty-two in total, out of which, the first sixteen belongs to the earth and the next sixteen to the sky. There are six sthanas or 'stances' to be resorted to by men while engaging in conversation, expressing certain sentiments etc. All this artificial gesticulation and stylish body language transforms any emotion into a beautiful kinetic form which takes natya into the realm of fantasy, helping the process of rasanubhava that is the aesthetic flavour of the universalized emotion to be experienced by the spectators through the art of theatre. In this fashion, the holistic use of all the organs of human body comes under angikabhinaya.

Vacikabhinaya: is the expression through speech. It includes the actor's skill at delivering the dialogues as well as the dramatist's mastery at using the correct language. Bharata has discussed in detail the different vrttas or 'metres' in poetry; the laksanas or 'figures of speech'; the gunas and dosas that is the strong and weak points of poetic writing as well as diction. According to Bharata, speech is the vocal representation of words and is the basic structure for building up drama. So, it is essential that this branch of expression should be very carefully used. Angika, aharya and sattvika abhinayas interpret the speech. All sastras or 'sciences' are given form in words and are controlled by them. So, all knowledge is gained through word or speech. Therefore, there is nothing that is superior to speech and it is the basis of all activities (Natyasastra ch.15 par. 1-3).

Speech has been described as the main structure of drama since it affords the canvas for expressing all emotions, the basis for the instrumental and vocal music that accompany histrionics expression and by itself is an independent branch of histrionic expression. Bharata has also stated that iti-vritta or plot is the main structure of drama. They are just the same, for there is no plot without words and words are the basis of speech. It is clear that the production and the text have an intimate relation. The absence of sets requires the text to give the audience, through the words of the playwright, location and scenic background. So, vacikabhinaya - that encompasses voice and speech has been dealt from the viewpoint of both the playwright and the actor.

The speech content in a Sanskrit play can be divided into two parts; vak or the 'spoken' word and gana or the 'sung' word. We shall discuss the latter term and its significance when dealing with the aspect of music. Vak or the 'spoken' word is the basic unit of dialogue and is an essential component as it has a major role in the study of Sanskrit drama. Ancient dramatists gave great importance to dialogues and proper dramatic delivery. By analyzing a spoken or written conversation between characters one may infer various things such as time of action, place of action, mood and their behavioural patterns etc.

The dialogue of a Sanskrit play has a number of functions. Apart from carrying forward the theme, it always lays the setting and describes feelings and emotions of the characters. In the course of a play, minute incidents not required for action, certain details that are not physically present or rather not necessarily required on the stage, what is to be known and only be heard by audience, parts of the story that have happened between two scenes or acts, confidential speech between characters; all of these were conveyed to the audience with the help of various conversational techniques. Some of those devices are prakasa ("aloud") that is what is to be heard by all, svagata or atmagata ("aside") that is what is not to be heard by all, janantika, ("personal address") that is mutual conversation in the presence of [other] persons by shutting out the others in the middle of a story by the hand with three fingers raised, tripataka in which the ring finger is bent down, the thumb slightly curved inward, and the other fingers are outstretched and apavarita ("confidence") that is a secret told by one actor to 
the another by turning around towards the character that is to hear the secret. Another conversation technique termed as akasabhasita has already been mentioned.

Aharyabhinaya: Drama adopts all forms of human behaviour depending on situations and interprets it to the audience through the art of abhinaya. Human behaviour is molded mostly by reactions of the mind expressed through the face, words and the body. These three aspects have become the three abhinayas - sattvika, vacika and angika in drama. All arts are imitative in nature. Drama is much more so. When one says that drama is an imitative art, one is fully aware that the inherent nature of the individual (the actor) is controlled by the thought process relating to the character taken up. When this subjugation is in respect of voice and speech it is vacikabhinaya, when it is in respect of movements and gestures, it is angikabhinaya, when it is in respect of responsive emotional reactions of the mind it is sattvikabhinaya and when it is in respect of figure and form, make-up and costume it is aharyabhinaya. When all these four aspects are homogeneously blended, it results in natya or 'drama.'

Firstly, make-up and costume should be in accordance with the age and nature of the character, followed by proper movements and gestures, then correct voice and speech and finally by responsive emotional reactions. Essentially in drama, figure and form provide the spectacle and are called rupa. Because rupa is assumed in a drama it is called rupaka. It may be interesting to note that a fourth of the total area of the physical theatre building is allotted to the green-room which in a way indicates the importance of make-up and costume. The greenroom is always behind the stage and is called nepathyagriha and all acts that promote the creation of a character by way of make up and costume, ornamentation are called nepathyavidhis. It is through make-up and costume that the audience is given a complete picture of the nature of the character, his nativity, period and state of mind, etc.

Aharyabhinaya is broadly divided into four kinds. Firstly, pusta denotes models to be used on stage as part of stage-setting. It is of three kinds: sandhima - joined together-is something made of mat, cloth, leather etc. vyajima - is made by a mechanical device. Cestima — wrapped up things, mountains, carriages, shields, Flag staffs, armours etc. made of leather. Secondly, alankara denotes garlands and ornaments to be used from head to feet, clothes to be worn by male and female characters of various regions, forehead marks, collyrium to be applied to eyes, colouring of the teeth and lips.

Thirdly, the painting of the face and certain other parts of the body known as angarachana is a very important component of aharyabhinaya. In Bharata's opinion the scheme of colour has symbolic significance. So, in order to distinguish the characters from one another specific colours were used by the Sanskrit dramatists to represent the complexion of kings, nobles, tribal, foreigners, foresters etc. Mukharaga - colouring of the face is another important component. When painting the face or the body, one must take into account the features of different regions. The natural colours to be used are white, blue, yellow and red. These basic colours can be mixed to form mixed colours and sub-colours called samyuktavarnas and upavarnas. Fourthly, Sanjivaincludes the devices used to represent four footed animals, birds and human beings and reptiles like serpents. The equipment like artificial weapons used in dramas is also discussed. upakarana or the 'properties' used in drama are to be made with light type of woods, bamboo, Lac, hide etc. Making of masks is also enumerated in detail.

Mask is basically an important part of theatre craft that has been connected with the rituals and Indian history since antiquity. Masks of different culture and times connote that masks existed since the ancient tradition. Even in recent times, the contemporary theatre tradition values the use of the different forms of masks to suit the persona of different characters in dramas and theatres. In South India, during Bhagavat Mela when the story of the child devotee Prahlada is staged, the player who depicts Narasimha, the Lion-god who slays the demon king Hiranyakashipu, wears a magnificent ritual mask richly coloured and bejewelled and effectively conveying the blood-curdling fury of Narasimha. This mask is itself an object of veneration and when not in use, is kept inside a temple and prayers offered daily. Indeed this practice of worshipping masks used in mythological plays is common in many parts of the country.

Masks continue to be a vital force within contemporary theatre, and their usage takes a variety of forms. They not only protect but also transform, disguise, and enhance the face. Raghavan suggests that Bharata recommended the use of masks for covering up of an actor's personal identity so as to enable him to physically and mentally transform into a totally new and different person that the character role demanded ("Sanskrit Drama in Performance" 23).

Aharya plays a relative role in Bharata's abhinaya depending on the vrtti ("style") or dharmi ("practice") of presentation. In kaisiki vrtti, which is full of dance and natyadharmi which involves symbolic gestures, aharya is represented with angika. For instance, in lasya or solo abhinaya presentation by a single dancer, the dancer portraying the nayika or 'heroine', describes the season of spring by showing the flowers and the bees with her hand gestures, the pleasant atmosphere by some dancing steps instead of using painted curtain or the other props. Instead of using real ornaments, flowers, garments etc., she shows them with actions and 
gestures while she is adorning herself to welcome her beloved. However, as in Kathakali, a symbolic use of costumes and make-up is also made to create a larger than life image in order to project the magnificent characters of the epics like Mahabharata. In Kathakali theatre, dominant colours of make-up like green, black, red are used symbolically to show different types of characters of the drama. It must be noted that aharya is the only external vehicle other than body, used in abhinaya. Marasinghe observes that masks were profusely used when arabhati style was represented in a play (411).

Sattvikabhinaya: Sattva is mind, so, sattvika, is that which a creation of mind is. In general terms, it may be defined as the capability of an individual to bring into being the pleasures and pains experienced by others, making them his own. Interpreted in the language of drama, Sattva means the mental capacity of the actor to identify himself with the character and his feelings. The playwright with the help of sattva, brings upon himself the experience of the emotions of a character he is creating, and incorporates them in his work. The actor, in turn, with the help of sattva makes these experiences his own and presents them on the stage, while the sympathetic spectator enjoys the representations on the stage through the same medium-sattva. The playwright, the actor and the audience will have the same experience, while writing, acting and witnessing a play respectively.

To find out the true nature of sattvika as conceived by Bharata, it is essential to take a closer look at what are defined as sattvikabhavas. These are mentioned to be eight. They are: stambha or 'motionless', a sort of numbness that comes out of emotional shock, sveda is 'perspiration', romanca or 'horripilation', a thrilled state of mind when the hair on the body stands erect, svarabhanga is a change in the tonal quality of voice due to overstress of emotion, vepathu or 'shivering', vaivarnya is a change in complexion of the face, asru or 'tears' and pralaya or 'fainting.' These eight form a separate category of emotions.

Perspiration and tears are not actually bhavas but anubhavas, physical reactions usually seen at the height of emotional experience. It should also be noted that these sattvikaanubhavas do not pertain to a particular emotion, for instance, tears start rolling not only with extreme sorrow but also with extreme joy. One's face can go red not only with anger but also with lajja or 'shyness.' The hair on body stands not only with fear but also with any so called 'touching' experience. So, it can be seen that the same sattvikabhavas can occur in absolutely contrasting emotions.

Another important point about the above mentioned sattvika is that the anubhavas that suggest perspiration or loss of colour cannot be 'acted' just as one can activate the movements of the other limbs. In other words, our brain cannot "order" the body to produce these actions as it can "order" the other anubhavas like bending the head down or looking sideways, walking up and down etc. These sattvikas are essentially the external reactions of the change in the internal body organisms which are activated by acute emotion alone. Sattvikas are indeed bodily reactions; yet this is where they differ from mere angika. In fact, only when sattvika underlines angika and vacika, the abhinaya is fully able to convey the emotive content of natya. The difference between mere angika, and 'angika infused with sattvika', can be clearly felt by the experienced spectator. It is easy to experience sattvikas in real life but to produce them in the make-believe world of natya requires tremendous concentration, knowledge of human mind and technical skill on the part of the actor as well as the dramatist. According to Bharata, a drama is considered to be of superior quality if sattvikabhinaya predominates. If it has an equal share with other types of abhinaya, then such a drama is considered to be of ordinary class. And, where the other types of abhinaya have a major role to play, collectively or severally, that drama is considered to be an inferior type.

Though, the western theatre and the theatres of the rest of the world have managed to win the attention of the modern Indian dramatist to a considerable extent, it is the antique grandeur of the ancient Indian dramatic tradition that has completely swept him off his feet, in the recent times. The Natyasastra is a colossal work on dramatic art and technique. The contemporary Indian dramatists and theatre practitioners may do well to explore it efficiently and effectively, not with a patriotic fervour but with a professional temperament not just for their personal success but also for the continuance of the Indian dramatic tradition.

\section{References:}

[1]. Bose, Mandakranta. Movement and Mimesis: The Idea of Dance in the Sanskritic Tradition. Ed. Bimal K. Matilal. Vol. 12. Dordrecht: Kluwer Academic, 1991. Print. Studies of Classical India Ser.

[2]. Choubey, Asha. "Sophocles and Indian Poetics: A Study of Oedipus in the Light of Rasa Theory." Studies in Comparative Literature. Ed. Mohit K. Ray. New Delhi: Atlantic, 2002. 23-38. Web.

[3]. Kane, P. V. History of Sanskrit Poetics. 4th ed. New Delhi: Motilal Banarsidass, 1971. Print.

[4]. Marasinghe, E. W. The Sanskrit Theatre and Stagecraft. New Delhi: Sri Satguru, 1989. Print.

[5]. Rangacharya, Adya. The Natyasastra: English Translation with Critical Notes. 3rd ed. New Delhi: Munshiram Manoharlal, 1999. Print. 